\title{
Dukungan Manajemen Puncak, Kemampuan Teknik, Pelatihan Karyawan dan Kinerja Sistem Informasi Akuntansi Perbankan
}

Dwinanto Priyo Susetyo ${ }^{1}$, Dadang Sadeli ${ }^{2}$, Surtikanti $^{3}$

${ }^{1}$ Universitas Pancasila, Jl. Raya Lenteng Agung, Jagakarsa, Jakarta Selatan, 12640

${ }^{2}$ Universitas Pendidikan Bandung, Jl. Dr. Setiabudhi No. 229 Bandung 40154 Jawa Barat - Indonesia

${ }^{3}$ Universitas Komputer Indonesia (UNIKOM), Jl. Dipatiukur 112, Bandung

I N F O A R T I K E L

JEL Classification:

M53

M41

\section{Keywords:}

accounting information

systems,

top management support,

technical capabilities,

training of employees.

\section{A B S TRACT}

This research is motivated by a number of banking companies are less able to provide good service to customers, especially relating to electronic transactions. The purpose of this study was to determine the effect of top management support, technical capabilities and training of employees on the performance of accounting information systems. This study used a survey by distributing questionnaires by 73 bank's employees as of accounting information systems. The test results show that support of top management and the ability of users of information systems affect the performance of accounting information systems but employee training has no effect on the performance of accounting information systems.

\section{A B S T R A K}

Penelitian ini dilatarbelakangi oleh banyaknya perusahaan perbankan yang kurang dapat memberikan pelayanan yang baik terhadap nasabah khususnya yang berhubungan dengan transaksi elektronik. Adapun tujuan dari penelitian ini adalah untuk mengetahui pengaruh dukungan manajemen puncak, kemampuan teknik dan pelatihan karyawan terhadap kinerja sistem informasi akuntansi. Penelitian ini menggunakan survei dengan menyebarkan kuesioner sebanyak 73 pegawai bank di wilayah Sukabumi. Sampel yang diambil dari populasi tersebut adalah pemakai sistem informasi akuntansi. Hasil pengujian menunjukkan bahwa dukungan manajemen puncak dan kemampuan pemakai sistem informasi berpengaruh terhadap kinerja sistem informasi akuntansi tetapi pelatihan karyawan tidak berpengaruh terhadap kinerja sistem informasi akuntansi.

\section{Pendahuluan}

Pada zaman globalisasi seperti sekarang ini, dunia perekonomian dan teknologi mengalami perkembangan yang pesat sehingga semakin memperketat persaingan antar perusahaan baik perusahaan dagang, industri maupun perusahaan jasa. Persaingan tersebut mengakibatkan per- masalahan yang ada dalam perusahaan semakin komplek. Dimana perusahaan berlomba-lomba untuk menyajikan informasi yang up to date tentang produk maupun kondisi perusahaannya.

Penyajian informasi yang akurat dan relevan diperlukan adanya media elektronik, 
apalagi dalam mengkomunikasikan hasil dari keuangan perusahaan, jika tidak menggunakan media elektronik maka perusahaan akan mengalami kesulitan terlebih lagi jika perusahaan yang ditangani adalah perusahaan besar. Semakin besar perusahaan maka data yang akan di olah juga semakin banyak. Selain menghemat waktu dalam pengerjaannya, media elektronik juga memiliki keunggulan lain yaitu menghemat penggunaan kertas dalam mengelola keuangan perusahaan serta dapat lebih mudah di akses dimanapun tanpa membawa laporan keuangan perusahaan yang notabene tebal. Serta bagi pengguna data dapat mengetahui hasil laporan keuangannya secara elektronik sehingga menghemat waktu yang ada dan selain itu dapat lebih menjaga lingkungan karena berkurangnya penggunaan kertas yang berlebihan (paperless).

Salah satu kewajiban perusahaan adalah memberikan suatu informasi dari hasil proses akuntansi setiap periodenya untuk memenuhi kebutuhan informasi keuangan bagi pihak internal maupun eksternal. Untuk dapat memberikan informasi akuntansi tersebut maka dibuatlah sebuah sistem informasi yang di kenal dengan sistem informasi akuntansi. Sistem informasi akuntansi juga di laksanakan pada industri perbankan. Karena bank merupakan lembaga yang berperan sebagai perantara keuangan antara pihak yang memiliki kelebihan dana dengan pihak yang memerlukan dana serta sebagai lembaga yang berfungsi untuk memperlancar lalu lintas pembayaran (PSAK No.31 tahun 2012). Maka dari itu penerapan sistem informasi akuntansi pada dunia perbankan sangat penting untuk memenuhi kebutuhan informasi akuntansi para penggunanya.

Belakangan ini dalam industri perbankan semakin banyak transaksi yang menuntut kecermatan dan ketepatan penyajian data baik transaksi internal maupun transaksi eksternal. Dalam hal transaksi eksternal pelayanan merupakan hal yang sangat penting karena mereka berhadapan langsung dengan konsumen (nasabah). Selain memerlukan informasi yang akurat dalam pengolahan datanya, sistem informasi yang ada pada bank juga digunakan untuk memudahkan nasabah dalam melakukan transaksi, pengambilan uang, pengecekan saldo dan lain-lain.

Falsafah yang mendasari kegiatan pokok bank adalah kepercayaan masyarakat, dimana bank akan menerima simpanan dari masyarakat dalam bentuk giro, tabungan, deposito berjangka dan memberikan kredit kepada pihak yang memerlukan dana (IAI, 2012:31 paragraf 1). Maka dari itu bank harus mampu menyediakan informasi yang berguna bagi nasabahnya. Akan tetapi berdasarkan informasi yang di peroleh peneliti bahwa pada saat ini banyak keluhan dari masyarakat tentang pelayanan dari pihak perbankan. Sebagai contoh : karyawan bank di inggris harus bekerja keras karena hampir 16 ribu keluhan dari para nasabah setiap hari mampir ke meja manajemen bank karena para nasabah mengaku kecewa dengan pelayanan yang di berikan (www.liputan6.com tanggal 17 oktober 2013), dan yang mendominasi masalah yang berhubungan dengan perbankan adalah kartu kredit, mulai dari jumlah tagihan yang tidak sesuai, sistem pembayaran yang bunga berbunga sampai dengan cara penagihannya yang tidak sopan begitu pula yang terjadi pada perbankan di Sukabumi, tiap hari pasti ada saja keluhan yang di sampaikan oleh konsumen. Hal yang sama juga di alami oleh penulis dimana penulis tidak melakukan transaksi menggunakan kartu kredit akan tetapi pada bulan berikutnya pada rekening muncul tagihan. Teller bank BRI tidak mau melayani transfer online yang dinginkan nasabah karenaberhubungan dengan saat tutupbuku (www. komplain.info tanggal 12/09/2013), Disamping hal-hal diatas kejahatan yang berhubungan dengan perbankan juga meningkat sebagai contoh bank danamon di bobol tellernya sendiri Rp 300 juta raib, teller Bank Danamon cabang Subang Jawa Barat melakukan pembobolan dengan cara memalsukan tanda tangan dan surat-surat syarat penarikan rekening (detiknews tanggal 10/10/2005), belum lagi kasusnya Melinda Dee mantan relationship manager citigold citibank, Melinda Dee menarik dana dari nasabah tanpa sepengetahuan pemilik melalui slip penarikan kosong yang sudah ditandatangani oleh nasabah. 
Dalam perbankan, pemprosesan akuntansinya sangat rumit dan kompleks mulai dari pembuatan rekening nasabah, penganalisaan transaksi yang terjadi, penjurnalan dan seterusnya sampai pada proses pembuatan informasi akuntansi mengenai seluruh kondisi perusahaan sangat bergantung pada sistem informasi akuntansi yang perusahaan gunakan. Sistem informasi akuntansi yang baik akan menghasilkan informasi yang baik pula. Oleh karena itu, pihak bank perlu melakukan evaluasi terhadap sistem informasi akuntansi yang mereka gunakan agar sistem yang sudah mereka pakai selama ini dapat sesuai dengan kebutuhan dan tuntutan kondisi perusahaan khususnya para penggunanya.

Komara (2005 menemukan bahwa keterlibatan pengguna, ukuran organisasi, dukungan top manajemen, formalisasi pengembangan sistem mempengaruhi kinerja sistem informasi akuntansi.

Almilia dan Briliantien (2007) hanya dukungan manajemen puncak yang berpengaruh terhadap kinerja sistem informasi akuntansi. Prabowo, dkk (2013) membuktikan bahwa adanya pengaruh pelatihan dan pendidikan pengguna sistem informasi akuntansi terhadap kinerja sistem informasi akuntansi, adanya pengaruh kemampuan pengguna sistem informasi akuntansi terhadap kinerja sistem informasi akuntansi, adanya pengaruh dukungan top manajemen terhadap kinerja sistem informasi akuntansi. Suharni (2012) membuktikan keterlibatan pemakai dan kemampuan pemakai mempunyai pengaruh terhadap kinerja sistem informasi akuntansi. Raflis (2011) menemukan pengaruh yang pelatihan dan dukungan manajemen puncak terhadap penerapan sistem informasi akuntansi.

\section{Telaah Teori dan Pengembangan Hipotesis}

\section{Agency Theory}

Teori keagenan dapat dipandang sebagai suatu versi dari game theory (Mursalim, 2005), yang membuat suatu model kontraktual antara dua atau lebih orang (pihak), dimana salah satu pihak disebutagent danpihakyang lain disebut principal. Principal mendelegasikan pertanggungjawaban atas decision making kepada agent, hal ini dapat pula dikatakan bahwa principal memberikan suatu amanah kepada agent untuk melaksanakan tugas tertentu sesuai dengan kontrak kerja yang telah disepakati. Wewenang dan tanggungjawab agent maupun principal diatur dalam kontrak kerja atas persetujuan bersama.

Scott (2000) menyatakan bahwa perusahaan mempunyai banyak kontrak, misalnya kontrak kerja antara perusahaan dengan para manajernya dan kontrak pinjaman antara perusahaan dengan krediturnya. Kontrak kerja yang dimaksud dalam penulisan ini adalah kontrak kerja antara pemilik modal dengan manajer perusahaan. Dimana antara agent dan principal ingin memaksimumkan utility masingmasing dengan informasi yang dimiliki.

Tetapi disatu sisi, agent memiliki informasi yang lebih banyak (full information) dibanding dengan principal di sisi lain, sehingga menimbulkan adanya asimetry information. Informasi yang lebih banyak dimiliki oleh manajer dapat memicu untuk melakukan tindakan-tindakan sesuai dengan keinginan dan kepentingan untuk memaksimumkan utilitynya. Sedangkan bagi pemilik modal dalam hal ini investor, akan sulit untuk mengontrol secara efektif tindakan yang dilakukan oleh manajemen karena hanya memiliki sedikit informasi yang ada. Oleh karena itu, terkadang kebijakan-kebijakan tertentu yang dilakukan oleh manajemen perusahaan tanpa sepengetahuan pihak pemilik modal atau investor.

\section{Asymetry Informasi}

Manajer sebagai pengelola perusahaan lebih banyak mengetahui informasi internal dan prospek perusahaan di masa yang akan datang dibandingkan pemilik (pemegang saham). Oleh karena itu sebagai pengelola, manajer berkewajiban memberikan sinyal mengenai kondisi perusahaan kepada pemilik. Sinyal yang diberikan dapat dilakukan melalui pengungkapan informasi akuntansi seperti laporan keuangan.

Laporan keuangan dimaksudkan untuk digunakan oleh berbagai pihak, termasuk manajemen perusahaan itu sendiri. Namun yang 
paling berkepentingan dengan laporan keuangan sebenarnya adalah para pengguna eksternal(diluar manajemen). Laporan keuangan tersebut penting bagi para pengguna eksternal terutama sekali karena kelompok ini berada dalam kondisi yang paling besar ketidak pastiannya (Ali, 2002). Para pengguna internal (para manajemen) memiliki kontak langsung dengan entitas atau perusahannya dan mengetahui peristiwa-peristiwa signifikan yang terjadi, sehingga tingkat ketergantungannya terhadap informasi akuntansi tidak sebesar para pengguna eksternal.

Situasi ini akan memicu munculnya suatu kondisi yang disebut sebagai asimetri informasi (information asymmetry). Yaitu suatu kondisi di mana ada ketidakseimbangan perolehan informasi antara pihak manajemen sebagai penyedia informasi (prepaper) dengan pihak pemegang saham dan stakeholder pada umumnya sebagai pengguna informasi (user).

Menurut Scott (2000), terdapat dua macam asimetri informasi yaitu:

1. Adverse selection, yaitu bahwa para manajer serta orang-orang dalam lainnya biasanya mengetahui lebih banyak tentang keadaan dan prospek perusahaan dibandingkan investor pihak luar. Dan fakta yang mungkin dapat mempengaruhi keputusan yang akan diambil oleh pemegang saham tersebut tidak disampaikan informasinya kepada pemegang saham.

2. Moral hazard, yaitu bahwa kegiatan yang dilakukan oleh seorang manajer tidak seluruhnya diketahui oleh pemegang saham maupun pemberi pinjaman. Sehingga manajer dapat melakukan tindakan diluar pengetahuan pemegang saham yang melanggar kontrak dan sebenarnya secara etika atau norma mungkin tidak layak dilakukan.

Adanyaasimetriinformasimemungkinkan adanya konflik yang terjadi antara principal dan agent untuk saling mencoba memanfatkan pihak lain untuk kepentingan sendiri. Eisenhardt (1989) mengemukakan tiga asumsi sifat dasar manusia yaitu: (1) manusia pada umunya mementingkan diri sendiri (self interest), (2) manusia memiliki daya pikir terbatas mengenai persepsi masa mendatang (bounded rationality), dan (3) manusia selalu menghindari resiko (risk adverse). Berdasarkan asumsi sifat dasar manusia tersebut menyebabkan bahwa informasi yang dihasilkan manusia untuk manusia lain selalu dipertanyakan reliabilitasnya dan dapat dipercaya tidaknya informasi yang disampaikan.

\section{Kinerja}

Kinerja merupakan sebuah istilah yang saat ini sering digunakan oleh masyarakat maupun organisasi swasta dan pemerintah. Kinerja mengarah pada suatu tingkat pencapaian tugas yang dilakukan oleh seseorang,

Suatu sistem pemroses informasi adalah sekumpulan komponen perangkat keras dan perangkat lunak yang memiliki kemampuan untuk memproses data melalui program-program yang ditulis. Dengan demikian istilah kinerja untuk suatu sistem yang memproses informasi adalah merupakan fasilitas-fasilitas yang dapat tersedia untuk dimanfaatkan yang meliputi bahasa pemrograman, utiliti yang digunakan untuk mendesain dan pengembangan program, utiliti pemrosesan, feature untuk memperbaiki kegagalan dan sebagainya.

Kinerja (performance) terdiri dari indeksindeks yang dapat melambangkan kemudahan, kenyamanan, kestabilan, kecepatan dan lainlain. Setiap indeks memiliki kuantitas dan kemudian menjadi obyek evaluasi. Suatu indeks performance dapat dievaluasi dengan berbagai cara, antara lain:

1. Dapat diukur (measured)

2. Dapat dihitung (calculated)

3. Dapat diperkirakan (estimated)

Evaluasi tersebut merupakan kuantitatif (sesuatu yang dapat dijabarkan dalam angka). Namun demikian banyak faktor dari sistem yang dipilih adalah merupakan kualitatif yang sukar untuk dikuantisasi.

\section{Kinerja sistem informasi akuntansi}

KinerjasistemmenurutSoegiharto(2001): "Merupakan penilaian terhadap pelaksanaan kegiatan dibandingkan dengan tujuan yang telah ditetapkan sebelumnya." Sedangkan Kinerja sistem informasi menurut Soegiharto (2001): 
"Kinerja sistem berarti penilaian terhadap pelaksanaan sistem tersebut, apakah sudah sesuai dengan tujuan yang telah ditetapkan atau belum".

Penilaian terhadap kinerja sistem merupakan kepuasan kerja yang didapat pemakai sistem dalam pengoperasian sistem, manfaat yang dirasakan oleh pemakai kaitannya dengan sistem yang digunakan serta frekuensi tingkat pemakai dalam penggunaan sistem.

\section{Dukungan manajemen puncak}

Setiap organisasi dalam usaha mencapai tujuan, dan mengukurnya sampai sejauh mana keberhasilan yang dapat dicapai, dan itu memerlukan dukungan manajemen puncak. Menurut Chen dan Paulraj (2004) mendefinisikan dukungan manajemen puncak sebagai berikut: "Berkomitmen pada waktu, biaya, dan sumber daya untuk mendukung supplier agar terjadi kemitraan pada jangka panjang dan perusahaan juga dapat berlangsung berproses secara stabil. Salah satu hal yang penting bagi manajemen puncak dalam menjalankan bisnis adalah harus dapat selalu mengembangkan dan menciptakan satunilaibagiperusahaanagar dapatmeningkatkan kinerja organisasi. "Sedangkan dukungan Manajemen puncak menurut Hasmi (2004) adalah: "Pihak yang bertanggungjawab atas penyediaan pedoman umum bagi kegiatan sistem informasi. Tingkat dukungan yang diberikan oleh manajemen puncak bagi sistem informasi organisasi dapat menjadi suatu faktor yang sangat penting dalam menentukan keberhasilan semua kegiatan yang berkaitan dengan sistem informasi." Langkah yang paling menentukan keberhasilan dari perencanaan sistem adalah langkah pertama yaitu mendapatkan dukungan dari manajemen puncak / atasan (wilkinson, 2009 : 250). Tugas utama dari pengembangan sistem adalah mengkomunikasikan dengan manajemen puncak mengenai rencana strategis perusahaan, faktor-faktor penentu kesuksesan dan tujuan keseluruhan. Dukungan manajemen puncak dapat diartikan sebagai keterlibatan manajemen proyek dan sumber daya yang diperlukan. Oleh karena itu dukungan manajemen puncak memegang peranan penting dalam menentukan semua kegiatan termasuk yang berhubungan dengan sistem informasi akuntansi yang merupakan salah satu sub essensial dalam suatu organisasi. Kinerja sistem informasi akan semakin baik jikalau manajemen puncak mendukung dalam pengembangan sistem informasi akuntansi.

\section{Kemampuan teknik karyawan}

Dalam perusahaan yang menggunakan sistem informasi akuntansi terkomputerisasi, kemampuan pengoperasian sistem oleh seorang user sangat dibutuhkan. Kemampuan berasal dari kata mampu yang berarti kuasa (bisa, sanggup) melakukan sesuatu, sedangkan kemampuan berarti kesanggupan, kecakapan, kekuatan (Tim Penyusun Kamus Besar Bahasa Indonesia, 1989: 552-553).

Kemampuan berkaitan dengan karakter individu karena setiap individu pasti memiliki kemampuan tetapi tingkat kemampuannya berbeda, meliputi antara lain : pengetahuan, pengalaman, keterampilan, bakat, kepribadian dan pendidikan. Oleh karena itu, perlu penyesuaian antara kemampuan individu dengan pekerjaan yang diberikan akan meningkatkan kinerja individual sumber daya manusia organisasi publik.

Kemampuan adalah kapasitas seorang individu untuk melakukan beragam tugas dalam suatupekerjaan. Seorangkaryawan harusmemiliki kemampuan intelektual yaitu kemampuan yang di butuhkan untuk melakukan berbagai aktivitas mental-berpikir, menalar, dan memecahkan masalah (stephen P robbins, 2007: 57). Kinerja sistem informasi akan baik kalau didukung oleh personil yang memiliki kemampuan teknik dalam mengoperasikan sistem informasi akuntansi berupa kemampuan dasar menggunakan aplikasi komputer dan kemampuan spesialis mengenai sistem yang di gunakan (Rizki Respati Prabowo, Sukirman, Nurhasan Hamidi).

\section{Pelatihan karyawan}

Apabila dirujuk dari segi literaturliteratur Manajemen Sumber Daya Manusia, yang dimaksud dengan istilah pelatihan adalah training yang secara umum dapat didefinisikan 
sebagai suatu upaya untuk meningkatkan kualitas kerja karyawan sesuai dengan bidang tugas yang dihadapi sekarang.

Latihan dimaksudkan untuk memperbaiki penguasaan keterampilan - keterampilan dan teknik- teknik pelaksanaan pekerjaan tertentu, terperincidan rutin. Pengembangan(development) mempunyai ruang lingkup lebih luas dalam upaya memperbaiki dan meningkatkan pengetahuan, kemampuan, sikap dan sifat - sifat kepribadian. (T. Hani Handoko, 2001 : 234)

Sikula (dalam A Anwar Mangkunegara, 2005: 43) mengemukanan bahwa

"Training is short-term eucation process utilizing a systematic and organized procedure by which non-managerial personal learn technical knowledge and skills for a definite purpose. Development, in reference to staffing and personal matter, is a long-term educational process utilizing a systematic and organized procedur by which managerial personal learn conceptual and theoritical knowledge for general purposes".

Pelatihan (training) adalah suatu proses pendidikan jangka pendek yang mempergunakan prosedur sistematis dan terorganisir dimana pegawai non manajerial mempelajari pengetahuan dan keterampilan teknis dalam tujuan terbatas.

Pelatihan merupakan salah satu cara yang diterapkankan manajemen untuk menambah kemampuan dan wawasan bagi pemakai sistem informasi akuntansi. Pelatihan diarahkan untuk membantu karyawan dalam melaksanakan pekerjaan mereka saat ini secara lebih baik dengan tujuan untuk membuat karyawan bereaksi dengan cara tertentu tanpa ragu. Dengan seringnya diadakan pelatihan, karyawan bagian sistem informasi akuntansi akan semakin terampil dan cekatan sehingga kinerja dari sistem informasi akuntansi akan semakin baik

Kerangka pemikiran dalam penelitian ini membahas masalah alur dari pemikiran konseptual secara sistematis yang di mulai dengan fenomena yang terjadi dimana kinerja sistem informasi akuntansi didalam organisasi tidak dapat memberikan informasi yang akurat dalam pengambilan keputusan. Sehingga pengguna sistem tidak mendapatkan kepuasan dalam pemakaian sistem informasi akuntansi dan outputnya secara maksimal. Kinerja sistem informasi akuntansi akan maksimal kalau mendapatkan dukungan dari manajemen puncak dalam penerapannya, dimana bentuk dukungannya adalah manajemen puncak menyediakan fasilitas dan peralatan, memotivasi karyawan dan mengadakan program pelatihan (2007:261-262). Dukungan dari manajemen tidak akan berjalan dengan baik kalau personil (karyawan) tidak mampu menjalankan sistem informasi akuntansi artinya bahwa karyawan di tuntut untuk mampu mengoperasionalkan sistem informasi akuntansi dengan baik untuk menghasilkan output (laporan keuangan) guna mendukung keputusan yang akan di buat oleh manajemen puncak. Kemampuan teknik personal dapat di tingkatkan dengan seringnya personil (karyawan diberikan pengalaman berupa program-program pelatihan dan pembelajaran sehingga kemampuan dalam memecahkan permasalahan hubungannya dengan pemakaian sistem informasi akuntansi menjadi semakin baik.

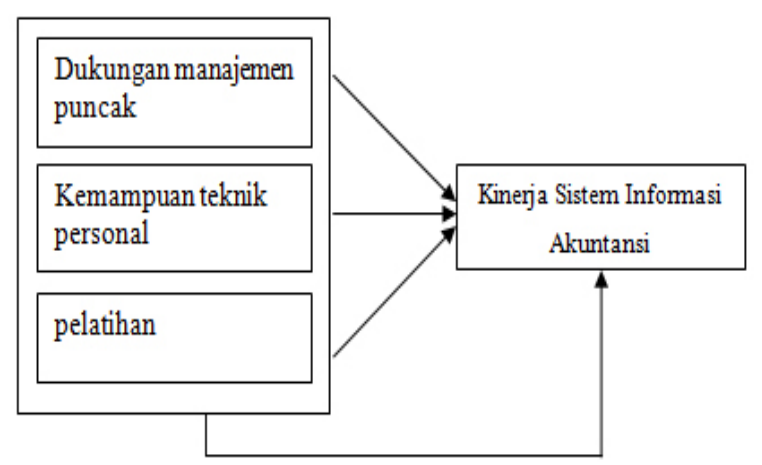

Gambar 1. Model kerangka pemikiran

\section{Metode}

Populasi dalam penelitian ini adalah staf perbankan yang terdapat di kota Sukabumi yang menggunakan sistem informasi akuntansi sebanyak 130 orang. Penelitian menggunakan metode penelitian survei group dimana informasi dikumpulkan dari responden satu group dengan menggunakan kuesioner. Survei group adalah survei yang pertanyaan-pertanyaannya 
diberikan kepada masing-masing responden dalam satu group tertentu (Jogiyanto,20011:8). Survei dibatasi pada penelitian yang datanya dikumpulkan dari sampel atas populasi untuk mewakili seluruah populasi.

Teknik pengumpulan data yang digunakan adalah dengan cara mengedarkan daftar pertanyaan yang harus diisi oleh responden yang akan dijadikan sampel dari populasi. Teknik ini dilakukan untuk mendapatkan data primer dan melengkapi data yang telah didapat dalam hal ini digunakan angket, yaitu memberikan daftar pertanyaan untuk diisi oleh responden yang menjadi sampel dalam penelitian.

Daftar pertanyaan yang telah disiapkan akan diberikan kepada responden dan hasil kuesioner yang telah diisi oleh responden akan dikumpulkan pada hari berikutnya untuk memberikan waktu kepada responden mengisi setiap pertanyaan yang ada dalam kuesioner. Uji Validitas dilakukan dengan teknik korelasi item dengan total skor. Uji reliabilitas dilakukan dengan kriteria cronbach alpha. Uji hipotesis dilakukan dengan Uji t, Uji Model penelitian dilakukan dengan melihat nilai koefisien determinasi dan hasil Uji F. Hasil uji validitas menunjukkan bahwa semua indicator yang digunakan untuk mengukur variable adalah valid. Hasil uji reliabilitas dapat dirangkum seperti pada tabel 1 .

\section{Hasil Penelitian dan Pembahasan}

Pengujian hipotesis dilakukan setelah uji asumsi klasik yang mencakup uji normalitas, multikolinearitas dan heteroskedastisitas. Uji autokorelasi tidak dilakukan karena data yang diuji merupakan data cross-section bukan data runtut waktu (timeseries). Hasil uji normalitas data digunakan untuk mengetahui apakah variable penganggu atau residual model regresi, memiliki distribusi normal atau untuk mengetahui apakah data yang diambil dari populasi berdistribusi normal. Model regresi yang baik adalah data berdistribusi normal atau mendekati normal, gambar grafiknya sebagai berikut :

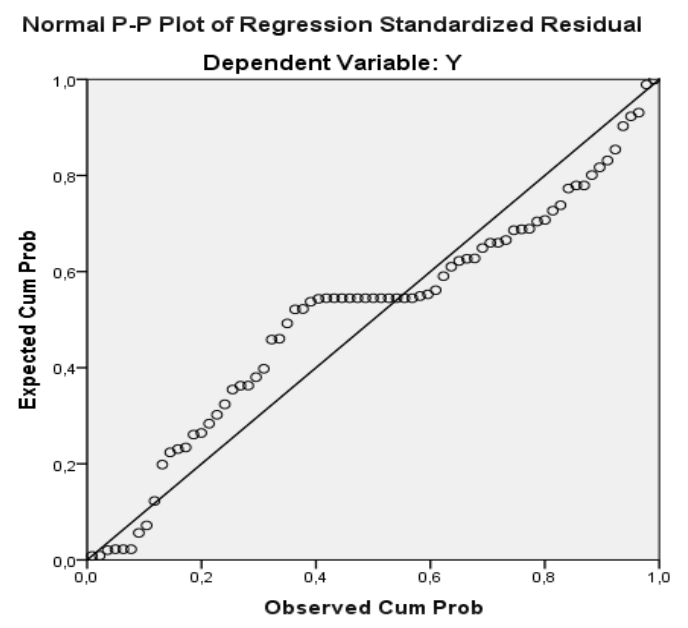

Gambar.2. Distribusi Normal Data

Tabel 1. Hasil Uji Reliabilitas

\begin{tabular}{lccl}
\hline \multicolumn{1}{c}{ Nama Variabel } & $\begin{array}{c}\text { Koefisien } \\
\text { Reliabilitas }\end{array}$ & $\begin{array}{c}\text { Titik } \\
\text { Batas }\end{array}$ & Keterangan \\
\hline Dukungan manajeman puncak & 0,850 & 0,6 & Reliabel \\
Kemampuan teknik & 0,696 & 0,6 & Reliabel \\
Pelatihan karyawan & 0,911 & 0,6 & Reliabel \\
Kinerja Sistem informasi akuntansi & 0,867 & 0,6 & Reliabel \\
\hline
\end{tabular}

Berdasarkan hasil pengujian nilai alpha antara 0,6 - 0,8 menunjukkan instrumen cukup reliabel. Dengan demikian maka instrumen variabel dukungan manajemen puncak (X1), kemampuan teknik (X2), dan kinerja sistem informasi akuntansi (Y) cukup reliabel yang artinya juga bahwa jawaban responden konsisten atau seragam.
Berdasarkan grafik di atas hasil distribusi data normal dapat kita lihat bahwa titik menyebar disekitar garis diagonal dan mengikuti arah garis diagonal. Nilai probabilitas pengamatan letaknya tidak jauh bahkan sebagian besar ada yang menempel pada garis diagonal sebagai nilai probabilitas harapan dan probabilitas pengamatan, sehingga bisa diartikan distribusi 
data kinerja normal.

Uji multikolineritas digunakan untuk mengetahui ada atau tidaknya penyimpangan asumsi klasik multikolinieritas yaitu adanya hubungan linear antar variabel independen dalam model regresi. Prasyarat yang harus terpenuhi dalam model regresi adalah tidak adanya multikolinieritas. Berikut tabel hasil olahan SPSS 20. Berdasarkan hasil uji multikolinearitas, diperoleh nilai Variance Inflation Factor (VIF) $<10(\mathrm{X} 1=1,63, \mathrm{X} 2=2,353, \mathrm{X} 3=1,746)$. Hasil tersebut memperlihatkan perhitungan nilai toleransi tidak menunjukan nilai kurang dai 0,10 yang berarti tidak ada korelasi antar variabel independen yang nilainya lebih dari $95 \%$. Dan juga hasil perhitungan, maka dapat disimpulkan bahwa tidak ada multikolinieritas antar variabel bebas model regresi ini.

Uji heteroskedastisitas bertujuan menguji apakah dalam model regresi terjadi ketidaksamaan variance dari residual satu pengamatan kepengamatan yang lain.
Berdasarkan gambar grafik scaterplots diatas terlihat bahwa titik- titik menyebar secara acak serta tersebar baik di atas maupun di baawah angka 0 pada sumbu Y. Hal ini dapat di simpulkan bahwa tidak terjadi heteroskedastisitas pada model regresi

Pengujian hipotesis dilakukan dengan uji regesi linier berganda. Hasil pengujian sebagaimana terangkum pada table 2 .

Pengujian model penelitian (goodness of fit) didasarkan pada hasil uji koefisien determinasi dan hasil Uji F. Berdasarkan hasil pengolahan SPSS 20 diatas, diperoleh nilai $\mathrm{R}$ square sebesar 0,560 artinya adanya hubungan yang cukup kuat antara variabel bebas dukungan manajemen puncak, kemampuan teknik dan pelatihan karyawan terhadap variabel terikat kinerja sistem informasi akuntansi yaitu sebesar $56 \%$. Sedangkan sisanya dari perhitungan $100 \%$ - $56 \%=44 \%$ dipengaruhi oleh faktor lain yang tidak diteliti yaitu keterlibatan pemakai, ukuran

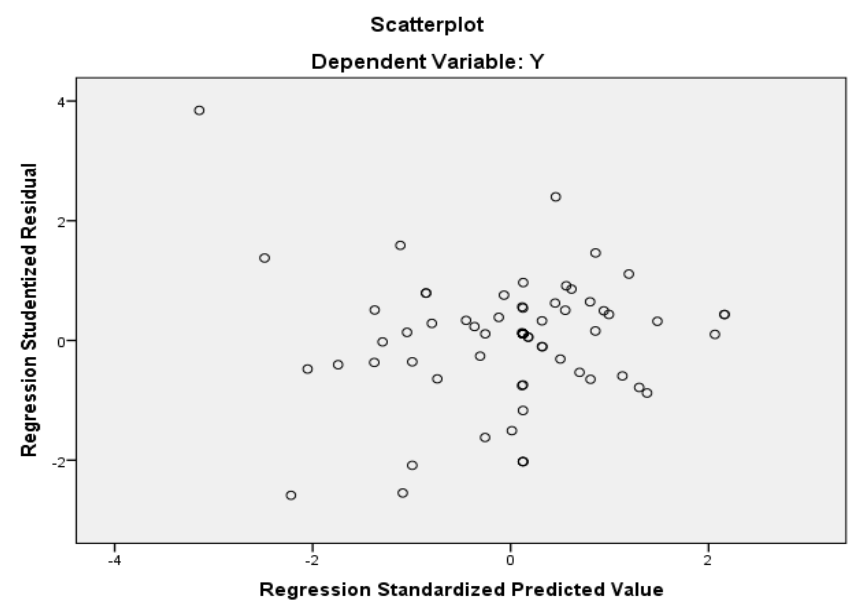

Gambar. 3.Hasil uji heterokedastisitas

Tabel 2. Rangkuman Hasil Pengujian

\begin{tabular}{lrrrc}
\hline \multicolumn{1}{c}{ Keterangan } & \multicolumn{1}{c}{ B } & Std. Error & t-hitung & Sig. \\
\hline Dukungan manajeman puncak & 0,546 & 0,110 & 4,977 & 0,000 \\
Kemampuan teknik & 0,356 & 0,136 & 2,624 & 0,011 \\
Pelatihan karyawan & $-0,004$ & 0,083 & $-0,046$ & 0,964 \\
Constant & 0,367 & 0,386 & & \\
R-Square & 0,541 & & & \\
Adjusted R-Square & 0,560 & & & \\
F-hitung & 29,262 & & & \\
Sig. F & 0.000 & & & \\
\hline
\end{tabular}


organisasi, formalisasi pengembangan sistem informasi, komite pengendalian sistem informasi, lokasi departemen sistem informasi. Dari tabel rangkuman hasil pengujian di peroleh nilai Fhitung 29,262 > Ftabel 2,50 dengan $\mathrm{p}$ value sebesar 0,000. Berdasarkan hasil tersebut dapat disimpulkan bahwa model regresi yang diuji adalah fit (baik).

Uji hipotesis penelitian mencakup hipotesis 1, 2, dan 3 dilakukan dengan uji t. Berdasakan hasil hasil uji $t$ dapat di bentuk persamaan regresi linier berganda sebagai berikut:

\section{$Y=0,367+0,546 X 1+0,356 X 2-0,004 X 3+e$}

Berdasarkan persamaan regresi tersebut nilai koefisien regresi dapat dimaknai sebagai berikut:

a. Nilai konstanta sebesar 0,367 berarti bila variabel Kinerja Sistem Informasi Akuntansi (Y) tidak di pengaruhi oleh ketiga variabel bebas ( Dukungan manajemen puncak, kemampuan teknik, pelatihan karyawan) konstanta atau bernilai nol maka besarnya nilai Kinerja Sistem Informasi Akuntansi sebesar 0,367

b. Koefisien regresi X1 bernilai posistif menunjukan adanya hubungan searah dengan Kinerja Sistem Informasi Akuntansi artinya bila X1 (Dukungan Manajemen Puncak) meningkat sebesar satu satuan maka akan menyebabkan meningkatnya Kinerja Sistem Informasi Akuntansi (Y) sebesar 0,546.

c. Koefisien regresi X2 bernilai positif menunjukan adanya hubungan searah dengan kinerja sistem informasi akuntansi artinya bila X2 (kemampuan teknik) meningkat sebesar satu satuan maka akan menyebabkan meningkatnya kinerja sistem informasi akuntansi (Y) sebesar 0,356

d. Koefisien regresi X3 bernilai negatif sebesar $-0,004$ artinya apabila pelatihan karyawan (X3) menurun satu satuan, akan berdampak pada penurunan kinerja sistem informasi akuntansi (Y) sebesar 0,004 satuan.

Hasil uji regresi menunjukkan bahwa dukungan manajemen dan kemampuan teknik berpengaruh terhadap kinerja sistem informasi akuntansi. Secara detil hasil pengujian dapat dideskripsikan sebagai berikut:

a. Untuk variabel Dukungan manajemen puncak(X1) di peroleh t hitung sebesar 4,977 $>$ t tabel 1.666 dan nilai p-value (sig) sebesar $0,000<\alpha 5 \%$ maka Ho1 di tolak dan Ha1 di terima. Artinya dukungan manajemen puncak (X1) mempunyai pengaruh yang signifikan terhadap kinerja Sistem informasi akuntansi(Y).

b. Untuk variabel Kemampuan teknik (X2) di peroleh $\mathrm{t}$ hitung sebesar 2,624 $>\mathrm{t}$ tabel 1.666 dan nilai p-value (sig) sebesar $0,011<\alpha 5 \%$ maka Ho2 di tolak dan Ha2 di terima. Artinya Kemampuan Teknik (X2) mempunyai pengaruh yang signifikan terhadap Kinerja Sistem informasi Akuntansi(Y).

c. Untuk variabel pelatihan (X3) di peroleh $t$ hitung sebesar $-0,004>t$ tabel 1.666 dan nilai p-value (sig) sebesar $-0,46<\alpha 5 \%$ maka H01 di tolak dan Ha1 di terima

d. Artinya pelatihan (X3) tidak mempunyai pengaruh yang kurang signifikan terhadap Kinerja Sistem Informasi Akuntansi(Y).

Pengembangan kinerja sistem informasi akuntansi tidak terlepas dari dukungan manajamen puncak. Dalam konteks system pengendalian manajemen, Pengembangan system merupakan salah satu kebijakan strategis. Kebijakan strategis diambil oleh manajemen untuk kepentingan jangka panjang perusahaan. Tujuan perusahaan adalah kinerja baik yang berkelanjutan. Oleh karenanya kinerja sistem informasi dapat meningkat jika manajemen puncak mendukung Pengembangan system informasi akuntansi diperusahaan. Sistem informasi akuntansi merupakan system yang mampu mendukung terciptanya informasi-informasi penting secara finansial dari aktivitas operasional berupa posisi keuangan perusahaan, laporan arus kas, laporan laba rugi, laporan perubahan ekuitas, dan laporan akuntansi lain yang dibutuhkan oleh manajemen secara internal. Tersedianya laporan keuangan untuk pihak eksternal bagi perusahaan publik memerlukan ketepatan waktu. Hal ini disebabkan oleh adanya regulasi terkait ketepatan waktu 
penyampaian laporan keuangan dan hal tersebut merupakan informasi penting bagi pihak eksternal untuk mengfambil keputusan, misalnya keputusan untuk berinvestasi ataukah tidak, keputusan pemberian kredit, keputusan melakukan company action, dan lain-lain.

\section{Simpulan, Keterbatasan dan Implikasi Hasil Penelitian}

Penelitian ini bertujuan untuk mengetahui faktor-faktor yang memengaruhi kinerja sistem informasi akuntansi yaitu dukungan manajemen puncak, kemampuan teknik dan pelatihan karyawan. Penelitian iniberfokus pada perusahaan perbankan di kota Sukabumi yang menggunakan sistem informasi akuntansi. Berdasarkan hasil penelitian maka dapat ditarik kesimpulan sebagai berikut.

1. Dukungan manajemen puncak secara parsial berpengaruhterhadapkinerja sisteminformasi akuntansi pada perusahaan perbankan di kota Sukabumi. Dukungan manajemen puncak dalam hal ini diukur dengan indikator Decision Quality (Keputusan yang berkualitas), Decision Acceptance (Penerimaan Keputusan), Satisfaction with the Decision Process (Kepuasan dengan proses Keputusan), Development of Participant Skills (Membangun keahlian partisipan) mempunyai pengaruh terhadap kinerja sistem informasi akuntansi yang berarti semakin tinggi dukungan manajemen puncak akan menjadikan semakin tinggi kenerja sistem informasi akuntansi pada perusahaan perbankan di kota Sukabumi.

2. Kemampuan teknik karyawan secara parsial berpengaruhterhadap kinerja sisteminformasi akuntansi pada perusahaan perbankan di kota Sukabumi. Kemampuan teknik karyawan dalam hal ini diukur dengan indikator tingkat pendidikan, pengalaman kerja, pengetahuan karyawan tentang sistem informasi, kemampuan karyawan mengoperasikan sistem, keahlian yang di miliki karyawan mempunyai pengaruh terhadap kinerja sistem informasi akuntansi yang berarti semakin tinggi kemampuan teknik karyawan akan menjadikan semakin tinggi kenerja sistem informasi akuntansi pada perusahaan perbankan di kota Sukabumi. Karyawan yang memahami sistem informasi akuntansi dengan baik akan dapat meningkatkan kinerja dari sistem informasi akuntansi.

3. Pelatihankaryawansecaraparsialberpengaruh negatif terhadap kinerja sistem informasi akuntansi pada perusahaan perbankan disukabumi. Pelatihan karyawan dalam hal ini diukur dengan indikator pelaksanaan programlatihan, metodepelatihan, identifikasi kebutuhan latihan, evaluasi hasil pelatihan. Pelatihan karyawan mempunyai pengaruh terhadap kinerja sistem informasi akuntansi yang berarti pelatihan karyawan berpengaruh negatif terhadap kinerja sistem informasi akuntansi. Berdasarkan data tersebut dapat disimpulkan bahwa program pelatihan karyawan yang dilakukan tidak memiliki pengaruh terhadap kinerja sistem informasi akuntansi pada perusahaan perbankan di kota Sukabumi.

4. Dukungan manajemen puncak, kemampuan teknik dan pelatihan karyawan secara simultan (bersama-sama) berpengaruh terhadap kinerja sistem informasi akuntansi pada perusahaan perbankan di kota Sukabumi

Berdasarkan hasil penelitian yang telah dilakukan, penulis bermaksud memberikan saran yang diharapkan dapat berguna sebagai bahan pertimbangan dan masukan untuk peneliti selanjutnya, diantaranya sebagai berikut:

1. Untuk meningkatkan kinerja sistem informasi akuntansi perlu dipertimbangkan faktor-faktor dukungan manajemen puncak, kemampuan teknik dan pelatihan terhadap karyawan

2. Pokok penelitian dalam penelitian ini adalah tentang faktor- faktor yang mempengaruhi kinerja sistem informasi akuntansi, dimana faktor yang diteliti hanya tiga faktor yang ada, nampaknya tidak cukup hanya satu kali pengamatan sebagaimana malalui pendekatan kuantitatif.

3. Pada penelitian berikutnya perlu dilakukan 
pengamatan dengan objek yang lebih luas, sehingga lebih dapat dijadikan acuan bagi kepentingan generalisasi permasalahan.

Penelitian ini memiliki keterbatasan yaitu hanya berfokus pada perusahaan perbankan di wilayah kota Sukabumi dengan sampel yang masih minim. Besar kemungkinan apabila sampel yang diambil dengan populasi yang besar akan mendapatkan hasil yang signifikan. Penelitian selanjutnya diharapkan mampu memerluas lingkup wilayahnya.

Penelitian ini juga hanya menggunakan kuesioner dan tidak disertai dengan wawancara langsung sehingga persepsi responden belum tentu mencerminkan keadaan sebenarnya.

\section{Daftar Rujukan}

Al Haryono Jusup, (2010). Dasar-Dasar Akuntansi Jilid I Edisi ke Enam, Penerbit BPFE, YKPN, Yogyakarta.

Al-Bahra Bin Ladjamudin, (2005). Analisis dan Desain Sistem informasi, Edisi Pertama, Cetakan Pertama, Penerbit Graha Ilmu, Yogyakarta.

Almilia, L.S dan Briliantien, I. (2006). " Faktorfaktor yang mempengaruhi kinerja pemakai sistem informasi akuntansi pada bank umum pemerintah di wilayah Surabaya dan Sidoarjo", (online), (http;//spicaalmilia.files. wordpress.com)

Arfan I. Lubis, (2010), akuntansi Keperilakuan, Edisi Dua, Penerbit Salemba Empat, Jakarta.

Dede Jaelani, (2010). Manajemen Sumber daya manusia, penerbit Thabi Press, Bandung.

George H.Bodnar dan William S.Hopwood, (2004). Sistem Informasi Akuntansi, Edisi kesembilan, terjemahan oleh Julianto A dan Lilis S, Penerbit Andi, Yogyakarta.

Setiawan, I. A., \& Ghozali, I. (2006). Akuntansi Keperilakuan: Konsep dan Kajian Empiris Perilaku Akuntan. Semarang: Badan Penerbit Universitas Diponegoro.

James A Hall, (2009). Sistem Informasi Akuntansi, Buku I, Edisi keempat, Terjemahan oleh Dewi Fitriasari dan Deni Arnos, Penerbit Salemba
Empat, Jakarta.

Jogiyanto, (2012). Metodologi Penelitian Bisnis, : Salah kaprah dan pengalaman pengalamannya, Edisi Kelima, Cetakan Pertama, penerbit BPFE Yogyakarta

Komara, A.(2006). "Analisis faktor-faktor yang mempengaruhi kinerja pemakai sistem informasi akuntansi". Jurnal Maksi. (online), Vol. 6, No. 2, (http;//ejournal.undip.ac.id)

Krismiaji, (2010). Sistem Informasi Akuntansi, Edisi Ketiga, Penerbit UPP STIM YKPN, Yogyakarta.

Lili M.sadeli dan Bedjo S, (2010). Akuntansi Manajemen,EdisiPertama, CetakanKeempat, Penerbit PT. Bumi Aksara, Jakarta.

Malayu S.P, (2000). Manajemen Sumber Daya Manusia, Edisi Revisi, Cetakan pertama, Penerbit PT Bumi Aksara, jakarta.

Mardi, (2011). Sistem Informasi Akuntansi, Cetakan pertama, Penerbit Ghalia indonesia, Bogor.

Raflis, R. Y. (2013). Pengaruh Pelatihan Dan Dukungan Manajemen Puncak Terhadap Penerapan Sistem Informasi Akuntansi (Studi Empiris Pada Perusahaan BUMN Di Kota Padang). Jurnal Akuntansi, 1(2).

Rizki Respati Prabowo, 2013 'Faktor-faktor yang mempengaruhi kinerja sistem informasi akuntansi di bank umum kota Surakarta". JUPE UNS Vol. 2, No 1, hal 119 s/d 130 (online)

Singgih Santoso, 2006. Seri Solusi Bisnis Berbasis TI, Penerbit PT. Elex Media Komputindo, jakarta.

Siti Suharni (2012) “ pengeruh keterlibatan pemakai dan kemampuan pemakai terhadap kinerja sistem informasi akuntansi pada sekretariat daerah dan BKD kabupaten Ngawi" (online)

Soegiarto. 2001. “ Influence factor affecting the performance of accounting information system". Gajah mada international journal of business vol 3. No 2 (online)

Sony.W dan Irene N, 2011. Akuntansi pengantar I : Sistem Penghasil Informasi Keuangan, penerbit AB Publisher, Yogyakarta.

Stephen P. Robbins dan Timothy A.Judge, 
(2008). Perilaku Organisasi, Edisi Dua Belas, terjemahan oleh Diana, Ria \& Abdul Rosyid, Penerbit Salemba Empat, Jakarta.

Sugiono, (2009). Metode Penelitian Kuantitatif, Kualitatif dan R\&D, cetakan Ketujuh, penerbit CV Alfabeta, Bandung.

Tata Sutabri, (2012). Analisis Sistem Informasi, Penerbit Andi Yogyakarta.

Teguh Wahyono, (2004). Sistem Informasi Akuntansi : Analis, Desain dan Pemograman Komputer, Edisi Pertama, Penerbit Andi, Yogyakarta.

Wahana Komputer, (2012). Short Course, SPSS 20, Penerbit Andi, Yogyakarta.

Yakub, (2012). Pengantar Sistem Akuntansi, Edisi Pertama, Penerbit Graha Ilmu, Yoygakarta. 